\title{
TOOLS OF THE TRADE: INTELLECTUAL PROPERTY ISSUES IN ELECTRONIC COMMERCE TOOLS
}

\author{
Heather A Harrison Dinniss*
}

This article explores some of intellectual property issues that arise out of the use of electronic commerce technology and tools. Part II of the article looks at the issues of ownership in the electronic commerce structure. The author examines the grant of patents for technology underlying the Internet and the emerging practice of granting patents for Internet business methods. Part III of the article explores the intellectual property issues which arise out of the use of associational tools such as hyperlinking, meta tags, framing and inline linking. These techniques are the tools of the trade for web site developers and lawyers seeking advise clients in relation to electronic commerce should be aware of the issues.

\section{INTRODUCTION}

Many articles have been written regarding the expansion of the Internet and the numerous legal issues that require lawyers to adapt, refine and reinvent our laws to cope with the novelty of a new environment and new technologies. Among these novel issues are the issues relating to the design and operation of the building blocks of the World Wide Web. The technologies that underlie the electronic commerce infrastructure and web sites in general. Web site design is being dictated by technologies that evolve according to user demand and the corresponding capabilities to meet that demand. ${ }^{1}$ Consequently, it is the duty of the law to respond to this evolution by ensuring that the same protections that are granted by intellectual property law in traditional aspects of commerce are extended into commerce conducted by electronic means. This is also the stated intention of the

* Heather Harrison Dinniss is a solicitor in the Information Technology and Intellectual Property team at KPMG Legal, Wellington and an adjunct lecturer at Victoria University. The author would like to take this opportunity to thank her colleagues at KPMG legal for their input and comments on drafts of this paper.

1 Mark Chancey "Meta-tags and Hypertext Deep Linking: How the Essential Components of WebAuthoring and Internet Guidance are Strengthening Intellectual Property Rights on the World Wide Web" (1999) 29 Stetson L Rev 203, 207. 
proposed laws governing electronic transactions in New Zealand. As a result of the increasing globalisation of the world economy, and as New Zealand moves forward into its promised knowledge economy these aspects of intellectual property law will become progressively more important.

This article focuses on the design aspects of the electronic commerce revolution and attempts to translate the jurisprudence from jurisdictions abroad into a New Zealand context. In doing so, the article will examine some of the common tools used in establishing a web site, in particular for those sites which have an electronic commerce component. Part II examines the actual ownership of the technology which makes up the infrastructure, both in terms of the technology which drives the Web and the business methods which have been developed or migrated into the e-commerce environment. Part III looks at some of the associational tools that are used by web sites to establish, maintain and increase their exposure and revenues on and through the Internet. Meta tags, hyperlinks, inline linking and framing are explained.

\section{OWNERSHIP OF TECHNOLOGY INCORPORATED IN E-COMMERCE INFRASTRUCTURE}

The technology incorporated into the Internet infrastructure and individual web sites is continually evolving as new and improved technologies are developed in response to user demand and increasing competition for a share of the online market. Further, relatively recently the United States has issued patents for the software and business methods utilised by e-commerce web sites. $^{2}$ The software underlying the operation of an ecommerce web site may also be protected by copyright laws. ${ }^{3}$ The laws in this area are particularly relevant to businesses seeking to establish e-commerce web sites and software programmers engaged in web site development.

In particular, the application of intellectual property laws to the use of such technologies faces increasing problems of globalisation. Traditionally, intellectual property laws are based on concepts such as territoriality and sovereignty. Each legal protection exists within a particular jurisdiction and cannot be enforced outside that jurisdiction. However, as the past few years have shown, the Internet largely ignores distinctions based

2 See for example the discussion of the recent United States case of State Street Bank $v$ Signature Financial in Part II B below (the decision upheld a patent for a particular business model for managing an investment portfolio).

3 A computer program is included in the definition of "literary work" in s 2 of the Copyright Act 1994. 
on territorial borders. Instead, the compatibility of infrastructure, code and language have thus far had a greater bearing on the reach of the Internet's currents. ${ }^{4}$

This infrastructure has provided a large melting pot and market place for new ideas, innovations and technological inventions. Not only is downloadable software and content the subject of copyright, often the principles and processes underlying the infrastructure itself have been made the subject of patent protection. Two developments in this area are of particular note, patents for technology underlying the World Wide Web as a whole and patents for business methods translated to the Internet.

\section{A Patents in Infrastructural Technology}

In June 2000, British Telecom sent out letters to the top Internet Service Providers ("ISPs") in the United States claiming that British Telecom holds the patent for the hyperlink technology which underlies the Internet. ${ }^{5}$ Hyperlinks are the foundation of the World Wide Web. Links embedded within web pages allow users to "jump" to another web page at the click of a mouse. The method allows a user to connect to other web pages and retrieve information within seconds and without having to perform new searches or other complex tasks. ${ }^{6}$ Hyperlinks may be represented by text or graphics. Hypertext generally appears as coloured and underlined text, where as hypergraphic links may be represented as an icon or graphic of any size or shape.

British Telecom's letters make moves to demand license fees for the use of hyperlinks on web pages operated by the ISP's. The licence demands are based British Telecom's patent for an information handling system, which was applied for in 1980 and granted in 1989. ${ }^{7}$ The patent refers to "an information handling system in which information is derived from a computer at a remote point and transmitted via the public telephone network to terminal apparatus". ${ }^{8}$ Critics claim that any application to enforce the patent will not be successful, however to date no legal challenge has been mounted against British

4 World Intellectual Property Organisation "Primer on Electronic Commerce and Intellectual Property Issues" <http://ecommerce.wipo.int/primer/section3.html> (last accessed 10 October 2000)

5 Craig Bicknell "British Telecom: We Own Linking" Wired News 19 June 2000 $<$ http://www.wired.com/news/politics/0,1283,37095,00.html> (last accessed 14 November 2000).

6 Jeffrey Kuester and Peter Nieves "Hyperlinks, Frames and Meta Tags: An Intellectual Property Analysis" (1998) 38 IDEA: J L \& Tech 243, 246.

7 Information handling system and terminal apparatus therefor, US Patent No 4,873,662

8 The full text of the patent is available at United States Patent and Trademark Office web site $<$ http: / / w w w.uspto.gov> (last accessed 5 December 2000). 
Telecom's claim. British Telecom has suggested that it may seek a declaratory judgement from the US Patent Office or the US courts in order to settle the issue. In the event that this patent is found to be valid, the consequences to the Internet would be profound. ${ }^{9}$

So could the patent succeed? There are several possible defences against British Telecom's claim, including an assertion that the patent has not been infringed. This is based on the argument that the patent refers to teletext technology rather than hypertext. Teletext is a system of retrieval whereby television viewers use their remote controls to enter numbers corresponding to pages of information available to them. Further, an argument may be made that regardless of the validity of the patent, it is the web site owners, rather than the ISPs who should be responsible for paying any licensing fees. ISPs argue that the use of hyperlinks on a web page is at the sole discretion of the owner of the page and that ISPs should not be responsible for their inclusion. British Telecom's election to pursue the ISPs raises another minefield of other legal issues in relation to third party liability and the Internet which cannot be dealt with in any detail in this article. ${ }^{10}$

The major defence against the British Telecom patent rests on the existence of prior art that shows that the patent may not be novel. In the early 1960's Ted Nelson began a project known as Xanadu, the original hypertext project. ${ }^{11}$ Xanadu is a hypertext and interactive multimedia system. According to the project history Nelson formulated the idea of hypertext in 1960, and worked on the idea independently between 1960 and 1970. The word hypertext was chosen in 1963, and first published 1965. In the 1970's Nelson joined forces with other programmers to implement the software. The Xanadu hypertext model is based on sideways connections among documents and files. It is optimised for a point and click universe where users jump from document to document by following links. ${ }^{12}$ However, the most damning evidence of this prior art to British Telecom's claim is a paper presented by Nelson and others in 1969 to the delegates of the Second University of Illinios Conference on Computer Graphics. The paper is titled "A Hypertext Editing System for the $360 "$ and described a system of dumb terminals running from an IBM 360/50 Mainframe,

9 Michael Patterson and Gabrielle Feely "The Internet starts to take Patents Seriously" (Address before the $14^{\text {th }}$ Annual IPSANZ Conference, 14 July 2000).

10 For a discussion of ISP Liability see, for example, Saba Hakim "Copyright and the liability of ISPs" [1997] 73(9) Law Institute Jnl 62.

11 See <http: / / www.xanadu.com> (last accessed 11 October 2000)

12 Paterson, above n 9, 5. 
using hypertext links. The description of the system set out in the paper has been paraphrased as follows: ${ }^{13}$

Areas of text may be connected in two ways: by links and or by branches. A link goes from a point of departure to an entrance point in another, or the same, text area. Links are optional paths embedded in the text. A point within an area may also be given a name (label) and later summoned by name to the screen. The user goes from area to area by "travelling" ("jumping") via a link or a branch, or by "getting" a label. The text is repositioned on the screen, so that the entrance-point is always at the upper left corer of the screen, and with as many text lines following it as will fit on the screen.

This reads very similarly to British Telecom's patent application. Further similarities also exist between other parts of the 1969 paper and the British Telecom patent. ${ }^{14}$ Therefore it appears that the system described by Nelson existed as "prior art" at the time of the filing of the patent and that the supposed invention of the British Telecom (then British Post Office) system was not novel. Additional evidence of the lack of novelty of the British Telecom claim has also been found in the archives of the Special Collections at Stanford University. On 9 December 1968, Douglas C. Englebart and a group of 17 researchers working with him in the Augmentation Research Centre at Stanford Research Institute, presented a 90 minute live presentation of an online system they had been working on since 1962. Although the main feature of the day was the demonstration of the computer mouse, many other innovations were displayed including hypertext, object addressing and dynamic file linking thus demonstrating hyperlinking 8 years prior to British Telecom's patent application. ${ }^{15}$

Based on this evidence, it appears likely that the patent will be held to be invalid and British Telecom will be unable to enforce any licence agreements entered into with ISPs for the technology. This patent claim does not directly affect New Zealand as the patent protection outside the United States has since expired. However, the principles which the claim represents have a global effect and have made the Internet community wary that infrastructural technology may not be as safe as once thought.

Many questions have been asked concerning the reasons why such a broad patent was granted in the first place. Much of the answer may lie with the size and rate of expansion

13 Greg Aharonian "British Telecom Patent: Lachey, Uninfringed and Invalid?" <http://www.oreillynet.com/pub/a/patents/2000/06/23/bt.html> (last accessed 12 November 2000).

14 Aharonian, above n 13.

15 Footage and abstracts of the presentation available at <http://sloan.stanford.edu/mousesite/ 1968Demo.html> (last accessed 16 October 2000). 
of the Internet itself. Approximately 30,000 web pages are added to the World Wide Web every 24 hours making it virtually impossible for patent officers to obtain a snapshot image of the Internet and its surrounding research as it existed at the priority date of the application. Finding a way to record the data available at any given time, let alone in a format that is easy to search is a huge problem. ${ }^{16}$

\section{B Patents for Internet Business Methods}

The second major change which affects the electronic commerce infrastructure is the introduction of Internet business methods as patentable subject matter. The recent explosion of patents in relation to Internet business methods can be seen as a direct result of the United States Federal Circuit case of State Street Bank and Trust $v$ Signature Financial Group, ${ }^{17}$ in which the US Court of Appeals for the Federal Circuit ruled that patents could be granted for business methods. The decision could have a big impact on the implementation of innovative e-commerce systems.

The invention in the State Street case involved a data processing system for managing information within their financial service business. The software, called Hub and Spoke, comprised of a system for implementing an investment structure for mutual funds. The system performed a series of complex financial calculations that essentially enabled several mutual funds or "spokes" to pool their investment funds into a single portfolio or "hub" organised as a partnership. The system tracked all relevant data determined on a daily basis for the "hub" and each "spoke" and enabled aggregate year end income, expenses and capital gain or loss to be determined for accounting and for tax purposes for the "hub" and, as a result, for each publicly traded "spoke".

Given the complexity of the calculations and the need for the calculations to be quickly and accurately performed, a computer or equivalent device was a virtual necessity. The case arose when negotiations for the licence of the software to State Street Bank broke down and State Street Bank brought a declaratory judgment action asserting invalidity, unenforceability and non-infringement of the patent. At first instance the application was granted and an appeal followed. The Court at first instance concluded that the patent was invalid because the claim subject matter fell into one of two judicially created exceptions to

16 Obviously, it is impossible to produce an exact figure for the number of web pages added to the web each day. The figure of 30,000 is the number of domain names added to the web each day. Each name registered does not necessarily convert into a web site as some names are bought but not set up and others may be bought to protect against 'cyber-squatting' and point to another web site. However may other names registered will have more than one page attached to the site. Readers should note that this is an extremely conservative estimate.

17 State Street Bank and Trust v Signature Financial Group (1998) 149 F 3d (Fed Cir)[State Street Bank]. 
patentable subject matter the "business method exception" and the "mathematical algorithm exception". 18

There are four major standards of patentability set out in the US Federal Patent Act. ${ }^{19}$ Those requirements are:

(1) The invention must be novel;

(2) The invention must be non-obvious to a person having ordinary skill in the art to which the subject matter pertains.

(3) The invention must be useful, in other words capable of producing a useful, concrete and tangible result; and

(4) The invention must be of patentable subject matter.

The State Street Bank decision significantly diminished the impact of the subject matter requirement on the patentability of Internet business models. Before this decision, two accepted principles of patent law relating to subject matter limited the patentability of methods of doing business on the Internet. These were the two exceptions identified by the court at first instance.

The first, the mathematical algorithm exception, provides that mathematical algorithms are not patentable subject matter to the extent that they are merely abstract ideas that are not useful. From a practical stand point, this means that in order to be patentable an algorithm must be applied in a useful way. It should be noted that a similar test has been adopted by both the Australian and New Zealand Patent offices. ${ }^{20}$ However, the Federal Circuit found on the facts that the "hub" and "spoke" software produced a useful, concrete and tangible result. Specifically, the Federal Circuit held that "the question of whether a claim is directed to statutory subject matter should focus on the essential characteristics of the subject matter, particularly its practical utility". ${ }^{21}$ The Court considered that the result was patentable, even if the useful result is expressed in numbers such as price, profit,

18 State Street Bank \& Trust Company v Signature Financial Group Inc. (1996) 927 F Supp 502, 516.

1935 USC $\S \S 101,102,103$.

20 This view is based on the tests of usefulness and practicality set out in the Australian decision on the National Research Development Corporation v Commissioner of Patents [1960] ALR 144. See also the discussion of patentability of Software set out in Hughes Aircraft Company Applications (8 February 1994) unreported, Commissioner Popplewell.

21 State Street Bank, above n 17. 
percentage, cost or loss. This effectively eliminated the mathematical algorithm exception as it related to computers and computer programs. ${ }^{22}$

The second ground for invalidating the patent was the so-called business method exception. The Court at first instance had invalidated the patent on the basis that the subject matter fell within a judicially created business method exception. The Federal Circuit took the opportunity to officially lay what they termed an "ill conceived exception" to rest. The Court stressed that business methods are no different than any other method or process and that patentability depends on whether the method, viewed as a whole, meets the requirements of patentability set forth in the United States Federal Patent Act, in particular the standards of novelty and non-obviousness.

Not surprisingly, the State Street Bank decision, resulted in a flood of patent applications. In 1998 alone, the United States Patent and Trade Mark Office issued around 17,500 software patents, 700 of which covered financial or business methods and more than 300 pertained to Internet ideas. ${ }^{23}$ Several of these patents have attracted a great deal of controversy. The following three examples are indicative.

The first such example is the patent granted to Priceline.com on 11 August 1998. ${ }^{24}$ Broadly speaking the PriceLine patent relates to a reverse auction scheme whereby buyers are able to name their own price for goods and services from large brand name companies. PriceLine initiated legal proceedings against Microsoft in October 1999, alleging that their Expedia hotel price matching system infringes the reverse auction patent. ${ }^{25}$ Microsoft obtained access to the source code which is the subject matter of the patent by claiming to be interested in assisting Priceline.com with the technological aspects. PriceLine claim that Microsoft's subsequent exploitation of the software breached the confidentiality agreements they were required to sign, as well as breaching the Unfair Trade Practices Act. ${ }^{26}$ However two independent companies have sought to challenge the PriceLine patent. Marketel has challenged the patent in a Californian court, however has sought to change jurisdiction to Connecticut, while Alden Enterprises has sought to challenge the

22 Chris Holt "Patentability of Internet Business Model" <http://www.ukans.edu/ cybermom/ CLJ/holt/holt.html> (last accessed 28 October 2000).

23 Statistics taken from the US Patent Office web site <http://www.uspto.govt $>$.

24 Method and Apparatus for a cryptographically assisted commercial network system designed to facilitate buyer-driven conditional purchase offers US Patent No 5794207.

25 Shannon Duffy "Priceline.com says Microsoft Stole Concept, Technology for Travel Service" The Legal Intelligencer, Philadelphia, United States of America, 14 October 1999, 3.

26 Dulty, above n 25 
patent with the US Patent Office. ${ }^{27}$ It seems that the argument over who the patent is owned by may need to be settled before the infringement case against Microsoft can be heard.

Another example is the patent granted to Open Market Inc covering the use of an "electronic shopping cart",28 a metaphor which allows merchants to provide customers with a mechanism for accumulating items for purchase before proceeding to the check out and paying.

The third example is the patented "one-click" system developed by Amazon.com. ${ }^{29}$ Critics have claimed that both the reverse auction system and the shopping cart metaphor have been commonly used in trade prior to the development of e-commerce. So why then have these patents been granted? The answer lies in the non-obviousness standard of the US Patent Act. To date, it appears that the mere transformation of a process from the real world to the Internet is sufficient to qualify as a non-obvious improvement. ${ }^{30}$ However, as more and more process are transferred to the Internet the obviousness of such a technique will become harder to prove. It seems likely that patents become restricted to those processes which are tailored to the specific structure of the Internet. The Priceline.com patent is a good example. Sales systems where pools of sellers select from the bids of customers have found little use in non Internet industries, however the Internet provides a unique commercial environment that is a particularly good match for the specific attributes of the sales system. ${ }^{31}$

The public policy justification for patents is, of course, that they encourage innovation by providing inventors with an economic incentive to disclose their inventions to the public. In return for full disclaimer the patentee receives a 20 year monopoly. ${ }^{32}$ The countervailing view with respect to patents for Internet business models is that the Patent Office is not really equipped to handle these patents and that examiners simply do not have sufficient expertise to evaluate patents which cover these models. Furthermore, the patent application process takes a very long time and the term of the patent, once granted, effectively confers a technological monopoly for 20 years.

\footnotetext{
27 "Expedia Makes Motion to Dismiss Priceline Patent Suit" Reuters, New York, 1 January 2000.

28 Network Sales System US Patent No 5715314.

29 Method and System for placing a Purchase order via a Communications Network US Patent No 5,960,411.

30 Holt, above n 22

31 Holt, above n 22

32 Patents Act 1953, s 30(3)
} 
Of course, to some extent these criticisms may be directed at patents for inventions generally, but the problem is particularly acute in an area that is developing and evolving as quickly as electronic commerce. 20 months is a very long period in the life of the Internet, let alone 20 years. It may be appropriate for public policy reasons to have a shorter period of protection for e-commerce inventions, say, 5 years.

To date, the Intellectual Property Office of New Zealand (IPONZ) has not granted patents for business methods, however software has become recognised as patentable subject matter. ${ }^{33}$ The justification for this approach is that business schemes and methods have traditionally been viewed as relating to intellectual activity rather than industrial activity and are therefore not considered as being a "manner of manufacture" under section 2 of the Patents Act 1953. For example, in Stahl \& Larsson's Application, ${ }^{34}$ it was held that "...however ingenious the alleged invention appeared to be, if in reality it was no more than a plan for the conduct of business in a particular way, it was not a manner of manufacture". ${ }^{35}$ Australia and the European Community adopt a similar approach. Article 52 of the European patent Convention currently excludes "schemes, rules and methods for doing business" from the scope of patentable inventions.

Given that Australian and European law follow the same line as the New Zealand approach, it is easy to overlook the relevance of the US patent law to New Zealand ecommerce businesses and software developers. However, the US developments are important to New Zealand in at least two respects. Firstly, New Zealanders who develop e-commerce web sites and business models should be aware of the advantages of seeking protection in the United States. The United States market conducts about $75 \%$ of the world's electronic commerce and priority publication in this market is a significant advantage. New Zealand businesses that wish to set up e-commerce sites within the infringement. Secondly, other countries are revisiting their own policies on granting patents for business methods in light of the developments in the United States. For example in the European Community there is now a strong movement to change European legislation to ensure a level playing field on a global scale. In October 1998, the UK Patent Office published an opinion on business methods in which it recognised that patents for ecommerce combine issues on the patentability of software with those relating to business methods. ${ }^{36}$ Further, given the inclusion of software as patentable subject matter in New

33 Hughes Aircraft Company Applications (8 February 1994) unreported, Commissioner Popplewell; Intellectual Property Office of New Zealand "Information for Clients" (29 September 1999) <http://www.iponz.govt.nz/iponz-docs/i/info4c_8.pdf> (last accessed 5 February 2001).

34 Stahl \& Larsson's Application (1965) RPC 596.

35 Stahl \& Larsson's Application (1965) RPC 596, 600 per Lloyd-Jacob J. 
Zealand, it appears likely that a similar approach will be adopted by IPONZ. By necessity, Internet business methods are often incorporated in software. Where that software meets the requirements of usefulness and practical application, ${ }^{37}$ IPONZ may well accept patents for the underlying Internet business methods.

The UK Chartered Institute of Patent Agents (CIPA) have expressed support for the requirements stated in Article 27 of the TRIPs Agreement, ${ }^{38}$ to which New Zealand is a party. Article 27 states that patents must be available for any inventions, whether products or processes, in all fields of technology provided that they are new, involve an inventive step and are capable of industrial application. CIPA commented that this provision should apply equally to software related inventions. To paraphrase one author, just because the end product of today's technological invention results in a string of bits, rather than bits of string, it is no less a piece of technology. ${ }^{39}$ It also follows that the provisions should apply to methods of doing business if countries outside the United States are not to suffer the competitive disadvantage of being unable to set up patent monopolies in the area of ecommerce while competitors in the United States can freely do so.

If other jurisdictions, such as the European Community and Australia amend their legislation in this regard, New Zealand may need to revisit its legislation.

Recently the US Patent and Trade Mark Office has also responded to concerns that the Office should overhaul its review process for awarding e-commerce patents. From now on, examiners who review e-commerce applications are required to search on-line databases to determine whether an idea is truly innovative. In principle, however, 20 year patents for novel e-commerce business methods will remain available. These methods may also be changed by a Bill introduced to the US congress on 3 October 2000 entitled the Business Method Patent Improvement Bill 2000. ${ }^{40}$ If passed the Bill will make several changes to the methods adopted for granting business method patents. Generally, patents

37 As well as the other requirements for patent acceptance such as industrial applicability, inclusion of an inventive element and non-obviousness, and other requirements set out in the Patents Act 1953.

38 Agreement on Trade-Related Aspects of Intellectual Property Rights, Including Trade in Counterfeit Goods (1994) 33 ILM 81 ["TRIPs agreement"].

39 Robert P Merges "As Many as Six Impossible Patents Before Breakfast: Property Rights for Business Concepts and Patent System Reform" [1999] 14 Berkley Technology Law Journal 577, <http://www.law.berkley.edu/journals/btlj/articles/14_2/Merges/html/text.html> (last accessed 11 October 2000).

40 Business Method Patent Improvement Bill HR5364 IH, $106^{\text {th }}$ Cong. (2000). The text of the Bill is available at <http://www.techlawjournal.com/cong106/patent/bus_method/berman.asp $>$ (last accessed 10 October 2000). 
would be harder to obtain and easier to challenge. One of the most important changes is the creation of a rebuttable presumption of non-obviousness for an invention that uses a computer to implement a known business practice. The Bill would also create a new, expeditious and inexpensive opposition process.

\section{COPYRIGHT ISSUES: LINKING, FRAMING AND META TAGS}

In addition to sparking controversy over the ownership of the technology behind the Internet, the ongoing results of using the technology have also been raising intellectual property issues. Associational tools such as hyperlinks, framing and meta tags have all had a impact on the intellectual property law over the past few years, however the issues are far from resolved. Each of these issues affects people wishing to partake in electronic commerce and practitioners need to be aware of the issues in order to advise their clients accurately. The paper will examine each in turn.

\section{A Meta Tags}

Meta tags are strings of invisible HTML code attached to a web page that identifies the contents of the web page. Meta tags contain such things as a general description of the page, keywords for search engines and copyright information. As such the HTML tags are a means of conveying information about information. Web site designers insert meta tags to label the site's content and reflect the likely keywords that a user will enter in a search engine search. As a general rule, the more keywords that match the users search request, the higher the web site will be ranked in the search results. Therefore, what information is included in a web site meta tag can affect the number of hits on the site and the order in which the site is ranked by search engines.

In the commercial context, web site success is measured by increased traffic to the site. Increased traffic and exposure ensure a greater likelihood that purchases will be made on the site, or that the owner can attract paying advertisers to the web site. ${ }^{41}$ This has led to a variety of tactics being adopted by the industry, including seeding the meta tags with keywords repeated over and over in a practice called spamming and using keywords which are popular search requests regardless of their relationship to the site. ${ }^{42}$ In response to such techniques the software developers responsible for search engines have developed features designed to spot spamming and consequently downgrade or exclude the site altogether. As search engines become more sophisticated in their abilities to collect and

41 Chancey, above n 1, 207.

42 Words such as "sex" and "nudity" are popular search terms. Over $50 \%$ of web usage is for adult entertainment. 
collate data from meta tags, renegade developers have had to adopt a different approach to getting their sites listed on top of a search request result list.

Developers have listed the name of a competitor or a competitor's products in the meta tags of their web page (and sometimes hidden such terms in the text of the page itself) in order to raise their ranking in the result list. The practice became relatively common in the web design trade and was listed in several Internet manuals as a legitimate web design technique. ${ }^{43}$ The courts have taken a fairly straight forward approach to this tactic: if the offending site has no legitimate claim to use the name, offenders have been held liable for passing off or trade mark infringement.

The leading case in this area for New Zealand is the United Kingdom case of Roadtech Computer Systems Ltd v Mandata (Management and Data Services) Ltd. ${ }^{44}$ In that case Mandata, a competitor of Roadtech, had used Roadtech's trade marks, the name of the company and the name of their flagship product ROADRUNNER in the meta tags of Mandata's web site. ${ }^{45}$ Roadtech sued Mandata, for passing off, and trade mark infringement in an action for summary judgement. Relying on the Mandata's admission of use of the trade mark, Master Bowman held that Mandata had infringed Roadtech's trade marks. Further, in its application for passing off, Roadtech submitted that Mandata had misrepresented to users searching for Roadtech or its products through search engines, that Mandata's web site and products were somehow connected with Roadtech. Damage was caused by misappropriation of Roadtech's goodwill and the poor quality of Mandata's web site, which might adversely reflect on Roadtech. Mandata put forward no positive defence to the claim to passing off and Bowman considered that all the necessary ingredients of passing off had been met. Consequently, he concluded that Roadtech was also entitled to summary judgment in respect of passing off. ${ }^{46}$

The original meta tag case was based on similar facts. In Playboy Enterprises Inc v Calvin Designer Label, ${ }^{47}$ Calvin Designer Label had used the registered trade marks of Playboy

43 Ann Davis "Web leaves a tangled Trademark Issue" Wall Street Journal, September 15 1997, B10, cited in Chancey, above n 1, 209.

44 Roadtech Computer Systems Ltd v Mandata (Management and Data Services) Ltd (25 May 2000) unreported, High Court, Chancery Division HC 199904573 per Master Bowman.

45 The Defendant had also used the trade marks in the text of the first page of the web site in the same colour as the background to avoid detection. The text would only show up to user when highlighted or printed but could easily be read by search engines.

46 Bird \& Bird "Unprecedented Judgement on Meta-Tags Delivered" International Law Office Newsletter 18 September $2000 \quad<$ http://www.internationallawoffice.com/1d.cfm? Newsletters_ Ref $=2357>($ last accessed 28 October 2000$)$.

47 Playboy Enterprises Inc v Calvin Designer Label (1997) 44 USPQ 2d (BNA) 1156 (ND Cal). 
Enterprises Inc ("PEI"), PLAYMATE and PLAYBOY, as terms in the meta tags of their web sites as well as in the domain names used for their sites. ${ }^{48}$ The district court ${ }^{49}$ issued a preliminary injunction ordering the defendant to cease all use of the PEI's registered trade marks including any terms similar to these trade marks, or any terms likely to cause confusion as a domain name, directory name or other such computer address, as the name of their service, in buried code or within meta tags on their web pages. The defendants were also enjoined from using the trade marks on the goods in any manner which might cause confusion or create the erroneous belief that that the goods or services were authorised, sponsored, licensed or in any way associated with PEI. Unlike the Roadrunner case however, this action cannot be said to based solely on the use of trade marked terms with in the meta tags of the infringing site because of the use of the trade marks in the domain name of the web sites.

Another case which highlighted the unauthorised use of trade marks, both as meta tags and domain names was the case of Brookfield Communications Inc $v$ West Coast Entertainment Corporation. ${ }^{50}$ In that case the plaintiff, Brookfield, had registered the trade mark MOVIEBUFF in respect of its searchable database of entertainment industry information. Brookfield issued proceedings to prevent West Coast Entertainment, a video store chain, from operating a site at moviebuff.com and using the term "moviebuff" in the meta tags of the site. West Coast had been using the mark in advertising campaigns for some time, describing itself as "the movie buff's movie store". The United States Court of Appeals for the Ninth Circuit reversed the trial judge's ruling that a temporary injunction should be denied. Although the court was dealing with the use of a trade mark in a domain name as well as meta tags, the interesting feature of this case is that the Court concluded that the unauthorised use of another's protected mark in ones meta tags is actionable under the US Lanham Act and expressly couched its decision in terms of an action for trade mark infringement. ${ }^{51}$

Given the role of trade mark law in the traditional commercial context, it is unsurprising that courts are keen to facilitate the use of established trade mark protections in the electronic market place. However, use of a trade mark in the web site's meta tags poses a difficult issue for traditional trade mark analysis and raises a question whether an action for trade mark infringement is an appropriate action for such use. The main premise

48 The defendants had registered the domain names <www.playboyyxxx.com> and $<$ www.playmatelive.com $>$ without the consent of PEI.

Northern District of California, San Francisco Division, per United States District Judge Legge.

50 Brookfield Communications Inc v West Coast Entertainment Corporation (1999) 174 F 3 d 1036 (9 Cir).

51 Above n 51, 1066 
behind an action for trade mark infringement is that the use of the mark creates a risk of confusion in the mind of the consumer.

Section $8(1 \mathrm{~A})$ of the New Zealand Trade Mark Act provides that a Part A trade mark is infringed where an unauthorised person uses, in the course of trade:

(1) an identical mark in relation to goods or services in the same class as the trade mark is registered;

(2) an identical mark in relation to goods and services which are similar to the class in which the trade mark is registered if such use would be likely to deceive or cause confusion; or

(3) a similar mark in relation to goods or services in the same or similar class as the trade mark is registered if such use would be likely to deceive or cause confusion.

AND in such manner as to render the use of the sign likely to be taken as importing a reference to some person having a right to goods (or services) with which such person is connected in the course of trade. Further where the mark is used with respect to goods the mark must be used on the goods, in physical relation to the goods, or in an advertising circular or other advertisement issued to the public. ${ }^{52}$ The problem with these requirements in respect of goods is that the meta tag is never seen by the public, it is only accessed by search engines.

In most meta tag cases to date, the issue of the "similarity" or not as the case may be, of the marks has not been addressed as the trade marks used in the meta tags have been identical and used in relation to competing goods or services. In cases such as the Roadtech Case above, the trade mark was used in the meta tag for a directly competing service. The following example illustrates the issues which arise with this clause. Imagine a shoe retailer, Sneaks, sets up a web site to sell their named brand of sneakers over the Internet. In order to promote their site in search engine ranking, Sneaks inserts the trade marks of their major competitors Nike and Reebok into the meta tags of their web site. Nike and Reebok discover this and bring an action against Sneaks for trade mark infringement. When a searcher looking to buy a pair of sneakers over the Internet enters the search term "Nike", web sites from both Sneaks and Nike appear. ${ }^{53}$ The marks being used are identical to Nike and Reebok's trade marks however the second arm of the test requires the mark to be used in a particular manner.

52 Trade Marks Act 1953, s8(1A)(e).

53 Given the way that search engines work it is almost certain that the official Nike site will come before the Sneaks site in any results list, as the official site will use the name repeatedly throughout the site. 
Where the mark refers to services, it is sufficient that the mark is used in relation to services to import a connection in trade. ${ }^{54}$ However, where the mark is in relation to goods, it must either be used on the goods, in physical relation to the goods, or in an advertising circular or other advertisement issued to the public. ${ }^{55}$ While there are no cases in New Zealand law, and the Roadtech case did not consider the question, it seems likely that a meta tag will fall within the advertisement category set out above in respect of goods and services.

The Trade Marks Act 1953 does not define "advertisement" and New Zealand trade mark case law does not provide assistance, however the Fair Trading Act 1986 defines an advertisement as "any form of communication made to the public or a section of the public for the purpose of promoting the supply of goods or services or the sale or granting of an interest in land". ${ }^{56}$ Undoubtedly an electronic commerce web site would fall within this definition, however, an issue may arise over whether a web site's meta tag is included in that definition. It seems likely that although the public is not presented with the meta tag information without additional effort, ${ }^{57}$ the nature of metadata as a description of the web page is such that it will be seen as an integral part of the web page.

The final issue is whether the use of the mark imports a reference to goods or services with which a person is connected in the course of trade. It is arguable from our example that the appearance of both sites in a search result for the search term "Nike", may give the purchasing public cause to wonder whether the Sneaks web site is connected to Nike in the course of trade.

Actions for passing off and misleading and deceptive conduct under section 9 of the Fair Trading Act 1986 may well also provide similar remedies. An action for intentional interference with business by unlawful means may also be possible. ${ }^{58}$

The Fair Trading Act 1986 provides that no person shall, in trade, engage in conduct that is misleading or deceptive, or is likely to mislead or deceive. The test of what is misleading or deceptive conduct is objective having regard to the circumstances and the

54 Trade Marks Act 1953, s 8(1A)(f).

55 Trade Marks Act 1953, s 8(1A)(e).

56 Fair Trading Act 1986, s 2(1).

57 The meta tags associated with any web page may be accessed by clicking the "Source" option of the "View" menu on a browser.

58 The tort of intentional interference with business by unlawful means may be available where the use of the trade mark is unlawful. The leading case on this tort is Van Camp Chocolates Ltd $v$ Aulsebrooks Ltd [1984] 1 NZLR 354 (CA). See also the case of Emms v Brad Lovett Ltd [1973] 1 NZLR 282 where loss of business to a shop constituted economic harm. 
persons likely to be affected. ${ }^{59}$ It should be noted however that misleading or deceptive conduct must go beyond merely causing wonderment, which falls short of actually misleading or deceiving the public or creating the likelihood of such a deception. ${ }^{60}$ Although the provisions of $\mathrm{s} 9$ are broader than the common law action of passing off. ${ }^{61}$

These actions are similar to other actions adopted in the United States under section 43(a) of the Lanham Act for passing off and false advertising. A landmark United Kingdom High Court ruling in August 2000 has also boosted the protection given to Internet meta tags. Lawyers Online, a legal Internet Service Provider, claimed that Lawyer on Line, a new entrant to the legal ISP market was using meta tags that diverted web users to its site. The Court held that Lawyer on Line must stop using similar meta tags to those used by Lawyers Online despite neither party having a registered trade mark. ${ }^{62}$

\section{B Hypertext Links - The Problem of Deep Linking}

Linking is another area of Internet technology which has caused problems for intellectual property laws. Linking is the practice of allowing another user to move from one page to another, or between web sites by simply clicking on a piece of text, logo or other graphic. As stated above, linking is the key to the Internet. Without the hyperlink technology users would be faced with an insurmountable amount of electronic information and no easy method of navigating through related pieces of information. However, in addition to possible patent claims in respect of ownership of the hypertext linking technology, a number of claims have been made regarding the practice of deep linking. Deep linking is the practice of providing a link to a web page which may be several layers deep within the referenced site. By contrast, surface linking provides a link to the outermost levels of the web site. It is this kind of surface linking which drives the web and is generally well received for increasing exposure and promoting awareness of the linked sites. $^{63}$

Deep linking on the other hand, has resulted in many law suits and looks set to continue to do so. So what is the problem? The issue results from the commercial nature of the web sites being linked to. As stated above, commercial web sites earn their keep by selling product from the site or selling advertising on the site. As a general rule, such

59 Savill v NZI Finance Ltd [1990] 3 NZLR 135 (CA).

60 Taylor Bros Ltd v Taylors Group Ltd [1988] 2 NZLR 1 (CA).

61 Bleiman v News Media (Auckland) Ltd [1994] 2 NZLR 673, 680 (CA).

62 Simon Mortlock "Metatags ruling keeps lawyers on line" 24 August $2000<$ http://uk.law.com> (last accessed 14 November 2000).

63 Chancey, above n 1, 229. 
advertising appears on the outer pages of a web site in banner ads or pop up screens. Therefore, if a referring web site links to a page deep within the target web site, they will bypass the advertising placed on the outer pages, and any promotional material, disclaimers and other information placed on the site by its authors. This results in lost revenue for the sites that have been linked, both through reduced advertising exposure and through missed sales of its own product. This was the argument of the plaintiff in Ticketmaster Incorporated $v$ Microsoft Corporation. ${ }^{64}$

\section{Ticketmaster v Microsoft Corporation ${ }^{65}$}

Microsoft had set up a local content web site called "seattle.sidewalk.com" which provided information about events happening in the city of Seattle in the US and included links to Ticketmaster to enable users to purchase tickets to attend such events, thus bypassing all policy and service information and more importantly, advertising presented on the site.

Ticketmaster argued on a number of bases, including false and misleading conduct and unfair competition, but the most interesting for the purposes of this article was the argument of dilution. When Ticketmaster submitted their original claim they had not specifically referenced deep linking, a situation that was amended by filing an amended complaint, implying that Ticketmaster realised the impossibility of arguing against a right to link generally. Microsoft, meanwhile, argued that Ticketmaster's stance breached an unwritten Internet code, whereby any web site operator has the right to link to anyone else's site as a natural and inherent part of the web experience. ${ }^{66}$ In addition to defences of estoppel, fair use and assumption of risk, Microsoft offered a defence based on its stated First Amendment right to publish public information. Microsoft also sought as declaratory judgement stating that hyperlinking was legal to avoid any chill "to the free workings of the Internet". The outcome of the case was eagerly awaited by Internet and First

64 "Ticketmaster Amended Complaint" National Law Journal, 12 May 1997, B02 (First Amended Complaint, CV 97-3055 RAP (CD Cal Filed 28 April 1997)) <http://www.jmls.edu/cyber/cases/ticket1.html> (last accessed 14 November 2000) [Ticketmaster Complaint].

65 Ticketmaster Complaint, above n 65.

66 Microsoft's answer included 11 positive defences, including assumption of risk, estoppel, fair use and rights under the first amendment. They also counterclaimed for a declaratory judgement to establish the legality of Hyperlinking to prevent any type of "chill" on the development of the Internet. The full text of Microsoft's answer may be found at <http://www.ljx.com/LJXfiles/ticketmaster/answer.html> (last accessed 12 November 2000). 
Amendment scholars alike. ${ }^{67}$ Unfortunately, the parties settled the case and the terms of the settlement agreement were subject to a non disclosure agreement. However, the outcome of the agreement is such that Microsoft no longer deep links to Ticketmaster's site but provides a link to their home page instead.

\section{Ticketmaster $v$ Tickets. com $^{68}$}

Ticketmaster has been embroiled in another argument over the legality of deep linking earlier this year. In the case of Ticketmaster Corp., et al v Tickets.com Inc Ticketmaster Corporation and Ticketmaster Online-CitySearch Inc (collectively referred to here as Ticketmaster) filed suit against Tickets.com, alleging that, in addition to deep linking into Ticketmaster's Site, Tickets.com had copied information from the site and posted false information about the availability of tickets from Ticketmaster. ${ }^{69}$ Tickets.com web site offered tickets for sale to the public, however it also provided information as to where and how tickets which it does not sell may be purchased. A short factual description as to the event, time, date place and price was listed for each event. Where Tickets.com did not offer tickets to the event itself, a hyperlink was provided to the user to take them to a site which did sell the tickets. It was that linking, along with allegations that Tickets.com had obtained its event information by 'spidering' Ticketmaster's site which led to Ticketmaster's claim filed in July 1999. Tickets.com filed a motion for dismissal of the claims.

On 27 March 2000, US District Court Judge Harry Hupp issued a ruling on the motion for dismissal. ${ }^{70}$ While widely touted by the news media as the decision to end the debate on the legality of deep linking, the judgement by no means provides a definitive roadmap to state when it is ok, and more importantly when it is not ok, to deep link to another site. $^{71}$

67 Bob Tedeschi "Ticketmaster and Microsoft Settle Linking Dispute" New York Times, 15 February 1999 Online <http://www.nytimes.com/library/tech/99/02/cyber/articles/15tick.html> (last accessed 12 November 2000)

68 Ticketmaster Corp et al v Tickets.com Inc (27 March 2000) unreported, US District Court, Central District of California, No 99-7654 HLH (BQRx) < http: / / w w w.gigalaw.com/library/ticketmastertickets-2000-03-27.html> (last accessed 12 November 2000); 2000 US Dist LEXIS 4553 [Ticketmaster v Tickets.com].

69 Margaret Smith Kubiszyn "Emerging Legal Guidance of 'Deep Linking" GigaLaw.com. May 2000 $<$ http://www.gigalaw.com/articles/kubiszyn-2000-05b-p1.html> (last accessed 12 November 2000) [Kubiszyn].

70 Ticketmaster $v$ Tickets.com, above n 68 .

71 Kubiszyn, above n 69, 5 . 
In dismissing the claim by Ticketmaster of copyright infringement, Judge Hupp stated: ${ }^{72}$

Hyperlinking does not itself involve a violation of the Copyright Act (whatever it may do for other claims) since no copying is involved. The customer is automatically transferred to the particular genuine web page of the original author. There is no deception in what is happening. This is analogous to using a library's card index to get a reference to particular items, albeit faster and more efficiently.

The copyright claim was revisited in August 2000, when the court ruled on the preliminary injunction. ${ }^{73}$ Ticketmaster claimed that the copying of the event page URL's on Ticket.com's site breached Ticketmaster's copyright and secondly that the cached copies of the information on Ticketmaster's site created by the spider software used by Tickets.com were unlawful copies. The court held that even though such "copying is transitory and temporary and is not used directly in competition with [Ticketmaster], ...it is copying and it would violate the Copyright Act if not justified". The court went on to find that the copying was justified based on the decision of Sony Computer Entertainment Inc $v$ Connectix Corp, ${ }^{74}$ which held that copying for the purposes of reverse engineering to obtain non-protectable information is protected by the fair use doctrine in certain circumstances. The court held that the analogy was appropriate in these circumstances as the copy was not used competitively, it was destroyed after its limited function was achieved, it is used only to facilitate obtaining non-protectable data and it was the most efficient way (although not the only way) to obtain the data. It is questionable whether such an interpretation could be made in New Zealand. New Zealand law does not contain such a broad fair use defence as the US law and such activities would be required to fall within the fair dealing provisions of Part III of the Copyright Act 1994. It is interesting to note however that a recent EU directive on the protection of computer programs has stated that copying for the purpose of reverse engineering is allowable. ${ }^{75}$ This may result in the

72 Ticketmaster v Tickets.com, above n 68, 6.

73 Ticketmaster Corp, et al v Tickets.com Inc [2000] Copy L Rep 28 (CCH), available at <http://www.gigalaw.com/library/ticketmaster-tickets-2000-08-10-p1.html> (last accessed 12 November 2000).

74 Sony Computer Entertainment Inc v Connectix Corp (2000) 203 F 3 d 596.

75 Council Directive on the Legal Protection of Computer Programs (13 December 1990) $91 / 250 /$ EEC. 
United Kingdom changing its laws, which to date are identical to the Copyright Act 1994 in material respects. ${ }^{76}$

Judge Hupp also allowed a motion for dismissal of Ticketmaster's claim for breach of the site's terms and conditions (which expressly prohibited commercial use of the site and deep linking) on the basis that Ticketmaster's claim failed to show that Tickets.com had knowledge of the terms and conditions posted on the web site or their agreement to them. He reaffirmed the view that merely putting terms and conditions on a web site at the bottom in fine print, does not necessarily create a contract with anyone using the web site. However, he granted leave to amend the claim in the event that Ticketmaster could show some evidence of Tickets.com's knowledge and implied agreement to the terms. ${ }^{77}$

Judge Hupp denied the motion to dismiss Ticketmaster's claims of unfair competition noting that the allegations that Tickets.com implied an association with Ticketmaster and gave misleading information about Ticketmaster could support such a claim. However on the allegation asserting deep linking as a form of unfair competition Judge Hupp stated the following:

The complaint also alleges deep linking as an example of unfair competition, but the court concludes that deep linking by itself (ie without confusion of source) does not necessarily involve unfair competition.

This approach is consistent with the court in the Shetland Times Case below.

\section{Shetland Times Case}

One of the first cases to be decided with respect to linking and of particular significance to the New Zealand context is the case of Shetland Times $v$ Wills. ${ }^{78}$ That case involved two rival newspapers who published in the Shetland Islands and was decided on the basis of section 20 of the Copyright, Designs and Patents Act 1988 (UK) which is identical to section 33 of the New Zealand Copyright Act 1994 and the determination that a headline may be an original literary work. The Shetland Times (herein after called the Times) sued the Shetland News (herein after called the News), when the News began offering links on its web site to stories posted on the Times' web site. The links on the News web site took the form of headlines and went deep within the Times web site to their articles section and

76 It should be noted that definition of copying in the United Kingdom Copyright, Designs and Patents Act 1998 Act differs significantly from the New Zealand definition, however in relation to reverse engineering the two Acts are identical.

77 The breach of contract theory was also dismissed at the preliminary injunction hearing in August 2000 for lack of sufficient proof of agreement by Tickets.com.

78 Shetland Times $v$ Wills [1997] FSR 604 [Shetland Times]. 
to the corresponding article, bypassing the Times' home page. In granting an interim interdict, Lord Hamilton found that it was crucial that all access to the substantive material on the Times web site should be obtained exclusively by accessing its web site through the home page. The decision was made on two grounds. Firstly, the Court attached copyright protection to the headlines used as hypertext links which had been copied directly from the Times site. ${ }^{79}$ The application of copyright protection to small phrases is an idea which has been criticised by some authors. ${ }^{80}$ Lord Hamilton indicated that there may be a question whether headlines, which are essentially brief indicators of the subject matter of the items to which they relate, are protected by copyright, however he declined to address the issue given the concession by the News that a headline could be a literary work: ${ }^{81}$

However, in light of the concession that a headline could be a literary work and since the headlines at issue (or at least some of them) involve eight or so words designedly put together for the purpose of imparting information, it appeared to me to be arguable that there was an infringement, at least in some instances, of section 17.

The second point of interest to New Zealand law was the classification of an Internet web site as a cable programme and the prima facie decision that the inclusion of the Times' headlines in the News' web site was an infringement of section 20 of the Copyright, Designs and Patents Act 1988 by the inclusion in a cable programme service of protected cable programmes. ${ }^{82}$ However, what is protected in terms of a cable programmes is the electronic signals making up the programme. This suggests that it is the code included in the link which is the infringing portion, rather than the headline itself.

However on November 11, 1997, both newspapers agreed to an out of court settlement. ${ }^{83}$ The terms of the agreement stated that the News would still be able to link to stories that are posted on the Times' web site by the use of headlines, but they must make sure that each hyperlink that goes to one of Times' stories uses the legend, "A Shetland Times Story," which must appear under the headline and in the same size; secondly, next to each headline there must be a button showing, "legibly," the Times' masthead logo; and finally, these legends and buttons are to be hyperlinks to the Times online headline page.

79 Shetland Times, above n 78, 609.

See for example Andrea Jane "Hyperlink Technology and the WWW - Trying on the "coat of copyright"" (1999) 38 Intell Property Forum, 14, 21. The discussion of the legitimacy of this decision is too broad a topic to be dealt with adequately in this article.

81 Shetland Times, above n 78, 609.

Shetland Times, above n 78, 608 .

83 Text of the Settlement Agreement is available at <http://www.jmls.edu/cyber/ cases/shetld2.html> (last accessed 12 November 2000). 


\section{Conclusion}

The Ticketmaster cases and the case of the Shetland Times are representative of the types of actions arising from the use of the deep linking technology. These deep linking cases emphasise one of the core ideological differences in Internet use. The proponents of the original spirit of the Internet as a source of community and sharing of information on a free access basis and the corporate players, intent on protecting brands and images who view the Internet as a commercial medium in which to exploit product for financial gain. While an argument can be made that surface linking is essential to the operation of the Web and that such linking is assumed when one consents to business on the Internet, deep linking appears to be perceived as more parasitic and as being a violation of the fundamental doctrines underlying unfair competition in the United States and similar doctrines relating to unfair trade practices in New Zealand law. ${ }^{84}$

\section{Framing}

The Shetland Times Case also raises issues in respect of another common associational tool that is used by web designers, the practice of framing or in-line linking. Framing, an advanced form of linking technology, is the practice of enabling another web page (or pages) to be displayed in a separate scrollable window on screen while remaining at the original site. ${ }^{85}$ Each window operates independently of the others, and when used properly, allows the user to navigate in an effective manner through the pages of the web site or to other sites on the Internet. Perhaps the most obvious use of framing technology is the use of a web site menu bar which remains on the screen no matter what web page on the site the user is currently viewing. Inline linking on the other hand does not appear to open another window, but rather are embedded within a text document. Inline links, usually to graphics, on the web page are actually HTML pages with links to graphics files stored on the server. The browser displays the text and images as if they were physically on the same page. We have dealt with inline linking in the same section as framing as, although there are no cases to date dealing solely with inline linking, the case law will be similar to that for framing. As inline linking is basically a more severe form of framing, all references to framing in this article include inline linking.

So what is the problem with framing? Framing allows a web page from an external site to be viewed on an unrelated site, or host site. This means that the text of the page may be viewed, not only without going through the linked sites home page and associated advertising, but also without the appearance of the user ever leaving the host site. A user

84 Chancey, above n 1, 233.

85 Older browsers do not support the frames feature, and many web sites have a frames and nonframes version of the site to accommodate them. 
will only see the URL of the host site and not the site being framed, which may result in confusion as to where the site is located. As stated above in relation to hyperlinks, web sites (particularly solely informational sites) obtain much of their revenue from advertising placed on the site. Framing allows the host site to avoid such advertising and indeed to replace the host sites advertising with its own.

That was the fact situation in Washington Post Co $v$ Total News. ${ }^{86}$ Total News operated a web site which provided links to news stories on numerous "name brand" news sources including the Washington Post, CNN, Time, Entertainment Weekly, Fortune and Money magazines, Sports Illustrated, and the Wall Street Journal. The Total News web site (totalnews.com) consists of lists of numerous "name-brand" news sources, including the trade marks exclusively associated with those sources. A description of the Total News service was provided in the complaint: ${ }^{87}$

\footnotetext{
When a user of totalnews.com "clicks" on one of those famous trademarks with the computer mouse, the user accesses a Plaintiff's corresponding website. (In Internet parlance, the trademarks here function as "hyperlinks": areas on the screen that, when clicked on, take the user directly to another website.) Plaintiff's site, however, does not then fill the screen as it would had the user accessed Plaintiff's site either directly or by means of a hyperlink from a website that does not "frame" linked sites. Nor does Plaintiff's URL appear at the top of the screen as it normally would. Instead, part of Plaintiff's site is inserted in a window designed by Defendants to occupy only a portion of the screen. Masking part of Plaintiff's site is the totalnews.com "frame," including, inter alia, the "Total News" logo, totalnews.com URL, and advertisements that others have purchased from Defendants.
}

The plaintiffs, Washington Post Company, Time Inc, Entertainment Weekly, Cable News Network, Reuters New Media and others brought multiple causes of action against the defendant Total News including misappropriation, federal trade mark dilution, trade mark infringement, false designation of origin, false representations, and false advertising, trade mark infringement and unfair competition under state law, deceptive acts and practices, copyright infringement and tortious interference. Although the case was settled out of court and the complaint dismissed on 5 June 1997, and therefore does not provide judicial guidance on framing the settlement agreement does indicate that at least one of the plaintiff's causes of action may have succeeded. The settlement agreement allowed the

86 The complaint, No 97 Civ 1190 (PKL) (SDNY complaint filed 20 February 1997) can be found at $<$ http://www.jmls.edu/cyber/cases/totall.html> (last accessed 13 November 2000). The complaint was dismissed on 5 June 1997 on settlement of the claim between the parties ["Complaint"].

87 Complaint, above n 43, para 30. 
defendant to continue to link to the plaintiffs web sites, but prohibited the use of any framing technology.

So what would the position be in New Zealand? The Shetland Times Case appears to indicate that the inclusion of a web page, which has been indicated to come within the definition of cable programme, in another web page may infringe section 16 of the Copyright Act 1994. Under section 4(5) of the Act, references to inclusion of a cable programme in a cable programme service are to transmission of the programme as part of the service.

However a possible defence may be made under section 87(1) of the Act. Section 87(1)(a) states that:

the showing in public of a ... cable programme to an audience who have not paid for admission to the place where the ... cable programme is to be heard or seen does not infringe any copyright in the .. cable programme.

Prima facie this appears to provide a defence to framing freely available information on the Internet in so far as claims based on the incorporation of cable programming is concerned as set out in the judgement in Shetland News.

A United States author has also made an argument that framing constitutes an unauthorised derivative work under the US Copyright Act $1976,{ }^{88}$ however New Zealand has no natural equivalent to the concept of derivative works. The closest equivalent is the provisions relating to infringement by making an adaptation of a literary work. ${ }^{89}$ The definition of 'Adaptation' is set out in the Copyright Act 1994 as follows:

"Adaptation",-

(a) In relation to a literary or dramatic work, includes-

(i) A translation of the work from one language to another;

(ii) A version of a dramatic work in which it is converted into a literary work or, as the case may be, of a literary work in which it is converted into a dramatic work;

(iii) A version of the work in which the story or action is conveyed wholly or mainly by means of pictures in a form suitable for reproduction in a book, or in a newspaper, magazine, or similar periodical;

88 Greg Lisby "Framing as an Unauthorised Derivative Work: Reconceptualising Traditional Approaches to Defining Copyright infringement" (1999) <http://gsulaw.gsu.edu/lawand/ papers / fa99/lisby/> (last accessed 16 October 2000).

89 Copyright Act 1994, s 34. 
(b) In relation to a literary work that is a computer program, includes a version of the program in which it is converted into or out of a computer language or code or into a different computer language or code, otherwise than incidentally in the course of running the program...

While the definition of Adaptation is inclusive, the particular acts specifically included by the definition all relate to the transformation of a work from one form or language into another. In contrast, the framing of a site on the Internet does not require such transformation and is more akin to a direct reproduction of the work than an adaptation. However, as the host site does not copy the content of the target site to its own site, but merely allows the user to display it (on the target site) while retaining the host sites' content as well, it may be likened to placing a piece of artwork in a frame. Although no case law exists on the topic, it appears likely that the definition of adaptation is not wide enough to include the reformatting of a work in the same language.

Other causes of action relied on in the Total News Case have equivalents in New Zealand Law. Actions under section 9 of the Fair Trading Act 1986, for misleading and deceptive conduct generally, may succeed where it is unclear that the framed page is from an external source. However it should be noted that such an action will only be successful where the offending site can be said to be in trade. Trade is defined under the Act to include "... any trade, business, industry, profession, occupation, activity of commerce, or undertaking relating to the supply or acquisition of goods or services or to the disposition or acquisition of any interest in land." 90 The definition has been interpreted widely by the courts and incorporates the definition of business which includes any undertaking that is carried on whether for gain or reward or not. ${ }^{91}$ This would cover any host site which receives payment for advertising on the site.

Actions for "reverse passing off", infringement of copyright in the text of the links and infringement of the moral rights of the author under the Copyright Act 1994 may also be used to combat framing depending on the facts of the case. Section 94 of the Act provides that an author of a literary work has the right to be identified as the author of the work provided that the right has been asserted. ${ }^{92}$ A simple statement on a web page to that effect will suffice. It should be noted however that this right does not apply to any computer generated work, for example, in the Ticketmaster $v$ Tickets.com case, Tickets.com

90 Fair Trading Act 1986, s 2(1).

91 Fair Trading Act 1986, s 2(1).

92 The requirement to assert the right of an author to be identified is contained in $\mathrm{s} 96$ of the Copyright Act 1994. 
would not be able to assert a right of authorship in respect of the web pages of which were created by the spidering software.

\section{CONCLUSION}

The Internet and the evolution of electronic commerce have provided access to markets around the globe which had hitherto remained inaccessible to some New Zealand producers because of our physical location in the world. However with these opportunities have come new challenges for lawyers. As indicated throughout this paper, the issues are many and complex and little judicial or statutory guidance is available. However, the laws in this area are particularly relevant to businesses seeking to establish e-commerce web sites and software programmers engaged in web site development. It is the job of lawyers and the courts to reinterpret and, where necessary, reinvent the traditional protections afforded to business in order to create a seamless environment in which business can operate. The starting point for this task must surely be the building blocks of the environment itself. Lawyers seeking to advise such clients must ensure that they are aware of the impact of the tools of their clients trade. 
